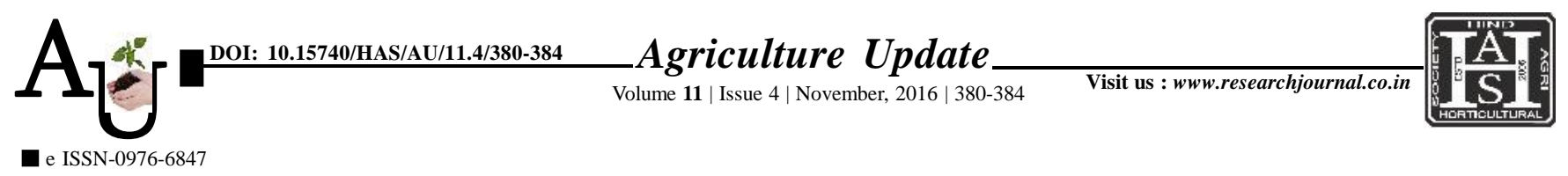

\title{
Research ARticle: Listeners knowledge and perception on programme broadcasted by KCRS in Dharwad
}

VISHWANATH S. NAIK AND N. MANJULA

Article Chronicle : Received :

08.08.2016;

Revised :

22.09.2016;

Accepted :

08.10 .2016

KEY WoRDS :

Knowledge,

Perception

Author for correspondence :

N. MANJULA

Department of

Agricultural Extension

Education, College of

Agriculture, University

of Agricultural Sciences,

DHARWAD (KARNATAKA)

INDIA

Email: drmnuasd@

gmail.com

See end of the article for

authors' affiliations
SUMMARY : The study was carried out to examine the Krishi community radio listeners perception about the farm broadcast and also to learn the impact on knowledge level of the listeners. The modern farm technologies evolved by scientists has tremendously helped the farmers to increase the farm production, still the big educated and innovative farmers were able to get the maximum benefits of new technology. The present study conducted in two villages of Dharwad district which is covered by KCRS Dharwad. The study revealed that the KCRS listeners were middle aged (30.00\%), had about upto middle school (25.00\%), medium extension participation and innovativeness. The listeners 37.50 per cent belonged to most favourale perception, majority felt that programmes were easy to follow and understand (67.50\%) and more interest to listen my voice and neighbors voice in the radio $(59.20 \%)$, majority of respondents has total knowledge index score of 68.18 for Jola and a score of 57.57 for maize was obtained in case of broadcasted dramatized programmes.

How to cite this article : Naik, Vishwanath S. and Manjula, N. (2016). Listeners knowledge and perception on programme broadcasted by KCRS in Dharwad. Agric. Update, 11(4): 380-384; DOI : 10.15740/HAS/AU/11.4/ 380-384. 